\title{
NEW OPPORTUNITY TO FARMERS: THE COMMODITY HEDGE
}

\author{
DEEPAK PAL \& LAVEENA SHARMA
}

Business Planning \& Development Unit, Jawaharlal Nehru Krishi Vishwa Vidyalaya, Jabalpur, Madhya Pradesh, India

In an ironic manner, we get news by the NCRB (National Crime Records Bureau), as 16,632 farmers, including 2,369 women, killed themselves last year (2014), constituting $14.4 \%$ of the total number of suicides in the country. A Situation of Farmers study undertaken by the NSSO (National Sample Survey Organization) of the Government of India indicates that $40 \%$ of farmers, given a choice wish to get out of agriculture. Agriculture is subjected to high risks because of the volatile nature of the factors involved. Herein, we poring on Price Movement risk to get a reasonable return on the time and money invested by farmers to get rid of aforesaid issue up to a great extent. To address it, integration of Farmer Producer Company \& Commodity Future market (hereafter-Commodity Market) looks to be one plausible solution via Hedging to offset the aforesaid risk.
\end{abstract}

Here, Key players are FPO (Farmer Producer Companies) \& Commodity Market. FPO as Lehman language “Group of farmers (producer) on the basis of symmetry in geographical conditions, Crop, land holding \& living status etc. to get the optimum return through conjoint effort." \& next is "Commodity Futures are contracts to buy/sell specific quantity of a particular commodity at a future date" through exchange. Key tool-The word hedge means protection. The dictionary states that to hedge are "Any technique designed to reduce or eliminate risk" and the term hedging is defined as the practices of protection from unwanted effects. In the context of futures/ commodity trading, that is precisely what a hedge is a counterbalancing transaction involving a position in the futures market that is opposite one's current position in the cash market.

These factors not only affected the farmer's livelihood and incomes but also put negative pressure on the viability of the agriculture sector and its potential to become a part of the solution to the problem of livelihood of the farmers and the allied labor. This paper is designed to help the farmers/ producers to manage their price risk with help of different tools i.e. future contracts etc. Although, it cannot able to cover full risk or it does not assure to cover complete risk but it is specifically capable to reduce or mitigate the risk up to a great extent. Under this we try to cover whole in short, overview of commodity market, FPO \& Hedging process, before spotlighting the New Opportunity to Farmers: The Commodity Hedge. We started with nitty-gritty introduction of pre-requisites. A principal objective of this paper is to better enable you to use such tools effectively. Research Methodology is based on analysis of secondary data that has been analyzed and interpreted with simple tools for sketch out the conclusions.

KEYWORDS: FPO, Future Commodity Market, Hedge, Producer Company \& Risk Management Tool

Received: Oct 05, 2017; Accepted: Oct 26, 2017; Published: Nov 16, 2017; Paper Id.: IJASRDEC201732

\section{INTRODUCTION}

The new era of commercialization is identified by a knowledge based playing with help of set of tactics instead of routine or traditional one. In Indian context, agricultural risks are linked with a variety of factors, ranging from climate Variability and change, frequent natural disasters, highly fickleness in yields and prices, weak rural infrastructure, imperfect markets and lack of financial services including limited span and design of risk reducing tools such as credit and insurance etc. Lack of awareness is also a backbreaker in this path. 
The criticality of agriculture in the rural transformation and the national economy seen along with its structural characteristics require substantial governmental and financial sector. The poor penetration and development of various risk management tools in the country also represent the huge opportunities for the emerging agricultural commodity markets to pull the producer from out of the poverty trap by insulating him from income shocks and by ensuring that a fair share of the price goes to the producer. In this context, this paper has futuristic view on why \& how FPO can help growers by taking part in commodity futures.

Risk implies future uncertainty about deviation from expected earnings or expected outcome. Risk measures the uncertainty that an investor is willing to take to realize a gain from an investment.

\section{RISK IN AGRICULTURE}

The various source of risk includes production, marketing, finance, legal areas \& human resource. Here we are specifically discussed the price risk (Marketing risks). Marketing risks are normally related to an imbalance between supply and demand and its effect on product prices. As supply and demand are inelastic in agriculture, markets are characterized by large changes in price. Growing condition vary over a period of time leading to over or under supply. This creates price risk. price risk is often the major source of risk, followed by personal \& institutional risk. As the demand for demand for agricultural commodities remains steady throughout the year, there are seasonal cycles of low prices at harvest, followed by higher prices later on as stocks diminish. Hedging, future contracting, storage, differed payments etc. are all means to sustain marketing risk. (Source-Indian agriculture \& Agri. business Management by Dr. Smita Diwase)

\section{WHY DIRE NEED OF IT}

Risk management continues to be one of the most neglected areas in Indian agriculture on account of various reasons.

- $\quad$ Lack of awareness of risk management tools. i.e. future market $\&$ insurance etc

- Low risk perception by the farmers. Risk perception varies from farmer to farmer depending on the farmers own experience and on the degree of risk aversion.

- Over dependency on government safety net programme, especially the PSS (Price support schemes) that have been playing a crucial role to reducing price risks for key products.

- Lack of corporate/private interest in it

- The above \& below things will give you a bird's eye view. A principal objective of this paper is to better enable you to use such tools effectively.

\section{PRIOR ART}

The Multi Commodity Exchange (MCX) and the National Commodity and Derivative Exchange (NCDEX) have tried to connect farmers with the exchanges through aggregators. For example, HAFED - an apex producer cooperative in Haryana - participated in the NCDEX wheat futures during 2006-2007 to hedge the member-producer risks. A combination of the closing out position and short hedging helped the cooperative reap profits of Rs. 108 a quintal. MCX took the initiative in 2008 to promote awareness among cotton growers in Gujarat. In collaboration with Cardinal Edge, a consultant and Aga Khan Rural Support Programme-I, an aggregator, NABARD funded the project; opening of a trading 
(demat) account was facilitated by Kotak Securities.

NCDEX also made a similar effort in association with the Institute of Financial and Management Research and the aggregator, Self-employed Women's Association in Gujarat. The project aimed to assess the impact of futures price access on the spot price expectation; it observed a significant change in price expectation between treatment and control farmers in project areas of Gujarat.

The Small Farmers' Agribusiness Consortium started promoting farmer organizations or Producer Companies (PCs) to enhance the market orientation of small growers. As of now, some 483 PCs have been registered to exploit economies of scale and scope of agricultural and allied markets. Amongst a large number of PCs, a few have been exposed to forward/futures markets albeit with a mixed experience. For example, Ram Rahim Pragati Producer Company of Dewas in Madhya Pradesh promoted in 2011 has become a member of NCDEX in forward trading, Samarth Kishan Producer Company is another example that has been capitalized in seed production and certification business since 2006. The collective enterprise is being exposed to forward trading and commodity-based financing. But because of awareness \& lack of knowledge, except for a few plantation PCs, the participation of aggregators in the market remains insignificant; this should be an area of concern for researchers and policy makers. In this context, given paper comprises in three sections, Overview of Commodity Market, FPO \& Tool to hedge as A, B \& C respectively.

\section{COMMODITY FUTURES MARKETS}

A commodity market (just like the equity market) facilitates trading in various commodities. It December be a spot market or a derivatives market. In a spot market, commodities are bought and sold for immediate delivery, whereas in a derivatives market, various financial instruments based on commodities are traded. These financial instrument such as 'futures' are traded in exchanges like Multi Commodity Exchange (MC X) and National Commodity Derivatives Exchange (NCDEX).

\section{The Futures Contract}

A futures contract is a commitment to make or take delivery of a specific quantity and quality of a given commodity at a specific delivery location and time in the future. All terms of the contract are standardized except for the price, which is discovered via the supply (offers) and the demand (bids). This price discovery process occurs through an exchange's electronic trading system or by open auction on the trading floor of a regulated commodity exchange.

All contracts are ultimately settled either through liquidation by an offsetting transaction (a purchase after an initial sale or a sale after an initial purchase) or by delivery of the actual physical commodity. An offsetting transaction is the more frequently used method to settle a futures contract. Delivery usually occurs in less than $2 \%$ of all agricultural contracts traded.

Table 1: Features \& Advantage of Future Contracts

\begin{tabular}{|c|l|}
\hline S. No & \multicolumn{1}{c|}{ Features \& Advantages } \\
\hline $\mathbf{0 1}$ & $\begin{array}{l}\text { Standardized contract in terms of contract size, delivery dates, quality, trading hours, tick size, and maximum } \\
\text { daily price limits; }\end{array}$ \\
\hline $\mathbf{0 2}$ & Exchange traded; hence, zero counterparty risk; \\
\hline $\mathbf{0 3}$ & Involves a 'down payment' known as the initial margin \\
\hline $\mathbf{0 4}$ & Transparent pricing \\
\hline $\mathbf{0 5}$ & Contract can be closed out prior to its maturity (giving an opportunity to cut losses); \\
\hline
\end{tabular}


(Source-http://www.lme.com/what_contracts_futures.asp)

\section{Exchange Functions}

The main economic functions of a futures exchange are price risk management and price discovery. An exchange accomplishes these functions by providing a facility and trading platforms that bring buyers and sellers together. An exchange also establishes and enforces rules to ensure that trading takes place in an open and competitive environment. For this reason, all bids and offers must be made either via the exchange's electronic order-entry trading system, As a customer, you have the right to choose which trading platform you want your trades placed on. You can make electronic trades directly through your broker or with pre-approval from your broker. For open auction trades, you must call your broker, who in turn calls in your order to an exchange member who executes the order. Technically, all trades are ultimately made by a member of the exchange. If you are not a member, you will work through a commodity broker, who be an exchange member, if not, will in turn work with an exchange member. Can a futures price be considered a price prediction? In one sense, yes, because the futures price at any given time reflects the price expectations of both buyers and sellers for a time of delivery in the future. This is how futures prices help to establish a balance between production and consumption. Futures prices adjust to reflect additional information about supply and demand as it becomes available.

\section{PRODUCER COMPANY}

It is a legal institution, registered under Company Amendment Act 2002 (1 of 2003) or also called Producer Company Act 2002. The new type is termed as 'Producer Company', to indicate that only certain categories of persons can participate in the ownership of such companies. The members have necessarily to be 'primary producers,' i.e., persons engaged in an activity connected with, or related to, primary produce.

\section{Primary Produce}

In terms of the Act it is a producer of farmers arising from agriculture including animal husbandry, horticulture, floriculture, pisciculture, viticulture, forestry, forest products, revegetation, bee raising and farming plantation products: produce of persons engaged in handloom, handicraft and other cottage industries: by - products of such products; and products arising out of ancillary industries.

\section{Formation}

Any ten or more individuals, each of them being a producer, that is, any person engaged in any activity connected with primary produce, any two or more producer institutions, that is, producer companies or any other institution having only producers or producer companies as its members or a combination of ten or more individuals and producer institutions, can get a producer company incorporated under the Act. The companies shall be termed as limited and the liability of the members will be limited to the amount, if any, unpaid on the shares. On registration, the producer company shall become as if it is a private limited company with the significant difference that a minimum of two persons cannot get them registered, the provision relating to a minimum paid-up capital of Rs. 1 lakh will not apply and the maximum number of members can also exceed 50. Members' equity cannot be publicly traded but be only transferred. As such, "producer companies would not be vulnerable to takeover by other companies or by MNCs.

\section{Members' Benefits}

Members will initially receive only such value for the produce or products pooled and supplied as the directors 
December determine. The withheld amount December be disbursed later either in cash or in kind or by allotment of equity shares. Members will be eligible to receive bonus shares. An interesting provision is for the distribution of patronage bonus (akin to dividend) after the annual accounts is approved — patronage bonus means payment out of surplus income to members in proportion to their respective patronage (not shareholding). Patronage, in turn, is defined as the use of services offered by producer companies to their members by participation in their business activities. Incidentally, there is an error in drafting — the powers of the board include "determination of the dividend payable" — it should have been "patronage bonus payable."

\section{TECHNIQUE \& OBSERVATIONS-HEDGING WITH FUTURES}

Here in after, we have sufficient knowledge about the term 'Commodity Market' \& the tool we can use as counterpunch against the price risk of agriculture produce of farmers is 'Hedge'. The core function of Hedge is to protect from the price risk $\&$ it works on the principle that future market prices $\&$ cash market prices have same directional movement whether it may up or down side, although movement is not necessarily quantitatively identical but it shows enough resemblance to optimum possibility of lessen the risk of price movement in cash market by taking an reverse position in the futures market. (Table No. 2)

Table 2: Price Movement

\begin{tabular}{|c|c|c|c|}
\hline S. No & & Cash Market & Future Market \\
\hline 01. & \multirow{2}{*}{ Price Trend } & UP 厅 & UP $\quad$ \\
\hline 02. & & Down $\square$ & Down \\
\hline
\end{tabular}

(Note-it assumes that cash market is directly proportional to the future market)

By opting reverse position, losses in one market would be offset by gains in the other market. In this manner, the hedger is able to establish a price level for a cash/physical market transaction that December not actually takes place for several months.

\section{The Short Hedge for Farmers}

To give you a better idea of how hedging works, let's suppose it is December and you are a wheat farmer with a crop in the field; or perhaps a processor with wheat you have purchased but not yet sold. The current cash market price for wheat to be delivered in March is Rs12.00 per kg. If the price goes up between now and March, when you plan to sell, you will gain. On the other hand, if the price goes down during that time, you will have a loss. (Table \& Diagram no. 3)

Table 3: Case of Profit or Loss

\begin{tabular}{|l|l|l|l|}
\hline \multirow{2}{*}{ S. No } & \multirow{2}{*}{ Month } & March Price is & $\begin{array}{c}\text { Effect to Sell } \\
\text { in Cash } \\
\text { Market }\end{array}$ \\
\hline 01. & \multirow{2}{*}{ Cash Market } & > December price & Profit \\
\cline { 3 - 4 } & & <December price & Loss \\
\hline 02. &
\end{tabular}




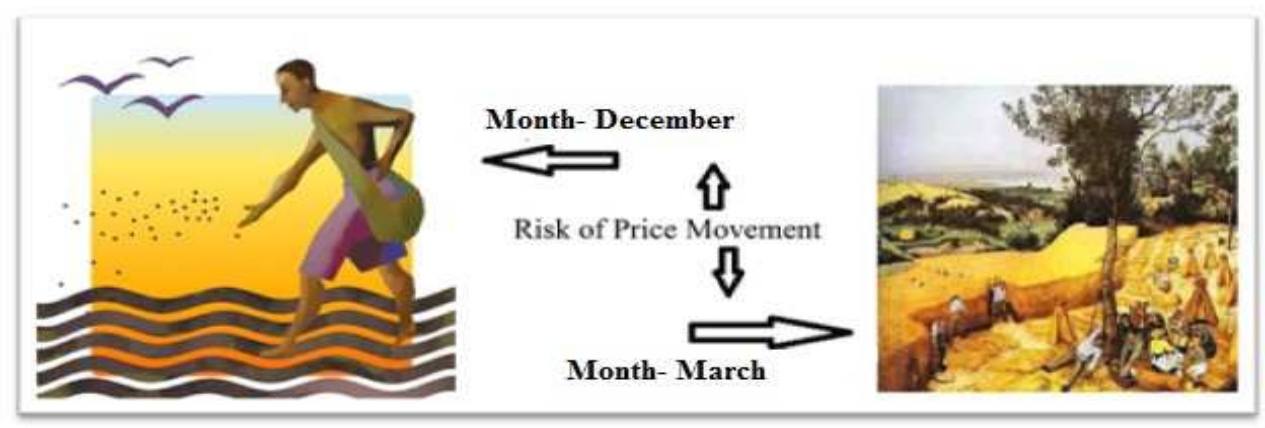

Figure 1: Case of Profit or Loss

To safeguard yourself against a unexpected downfall in price of commodity during the coming month, farmer can use the Hedge, There is a opportunity to short (sell) the lot size that is approx. equal to actual physical produce of farmer in same or related crop now and close the deal by long (buy) it back later when it is time to sell physical produce in the cash market. Henceforward, two situations are there, if the cash price goes down by the time of harvesting, any loss incurred will be offset by a earning from the hedge in the futures market. This type of hedge is called as a short hedge because of the initial short futures position. With futures, a open trade has compulsion to become a closed trade through following a position of short or long first and later long or short the position in any manner whether get a short or long position first and then go for opposite position to close the position likewise a person may sell first and buy later or buy first and sell later. Regardless of the manner in which the transactions occur, buying at a lower price and selling at a higher price will offer a gain on the futures position.

On other hand, at harvesting time, if price goes up in comparison to the month of sowing in physical/cash market then gain form physical market can offset the loss of future position vice versa.

For example, let's assume cash and futures prices are identical at Rs12.00 per Kg. What happens if prices decline by $\mathrm{Rs} 1.00$ per $\mathrm{Kg}$ ? Although the value of your long cash market position decreases by Rs1.00 per $\mathrm{Kg}$, the value of your short futures market position increases by Rs1.00 per $\mathrm{Kg}$. Because the gain on your futures position is equal to the loss on the cash position, your net selling price is still Rs12.00 per Kg. (Table No. 4)

Table 4: Price Movement

\begin{tabular}{|l|l|l|}
\hline \multicolumn{1}{|c|}{ Month } & \multicolumn{1}{c|}{ Cash Market } & \multicolumn{1}{c|}{ Future Market* } \\
\hline December & Cash wheat are Rs12.00 per kg & Sell March wheat future contact at are Rs12.00 per kg \\
\hline March & Sell cash wheat at Rs11.00 Per Kg. & Buy March wheat future at Rs11.00 per Kg. \\
\hline Difference & Rs1.00/kg loss & Rs1.00/kg gain \\
\hline $\begin{array}{l}\text { Sell Cash wheat at } \\
\text { Gain on future position }\end{array}$ & Rs.11.00/kg + Rs1.00/kg \\
\cline { 2 - 3 } Net selling Price & Rs.12.00/kg \\
\hline
\end{tabular}

Note: When hedging you use the future contract month closet to the time

*Excluding Transaction charges, AMC \& Brokerage.

\section{CONCLUSIONS}

The critical issues in Indian agriculture are related to knowledge and infrastructure. Although there isn't a lack of initiatives and institutions to tackle these issues, we have to become better at managing big systems to achieve success in our endeavours. At the same time, we should look into such approaches like Future Trading \& Price dissemination with 
proper integration of institutional bodies like FPO etc. This will ensure that agricultural sector remains viable and caters to the country's needs. Dissemination of prices \& Future Trading can provide useful inputs to farmers for decision making during pre-sowing and post-harvest period, Common national level platform for buying and selling of commodities, No counter party risk in trade, Customized services relating to storage and logistics, Availability of professional services for grading and standardization \& complete avoidance of hassles relating to physical market operations. Information of prices can improve the bargaining capacity of the farmers and reduce the monopoly of the middlemen at the agricultural produce markets and mandies. This would enable the farmers to get best possible prices for their produce.

In order to resolve the above difficulties and to accelerate the progress under Price movement risk, the government should adopt these steps such as Awareness program at grass root level, proper bridging between state \& central government, Arranging proper training session for Farmers, Granting more freedom to the farmer or not is something for policymakers to decide. Also encourage the SHGs/Framers producing Organisation to take positive move toward future trading as Risk mitigation tool. It is now on us farmers to work towards ushering in a digital era in years to come in India.

\section{REFERENCES}

1. Arun R. Joshi and Yogesh Kumar Dwivedi LEISA INDIA (March 2007) 'Producer Company - a new generation farmers institution

2. BS Reporter, New Delhi (May 4, 2013) 'Commodity futures market helped farmers, shows study' Retrieved from http://www.business-standard.com/article/markets/commodity-futures-market-helped-farmers-shows-study

1130504 00610_l.ht

3. Commodities. If mglobalin. Available at: http://www.ifmglobal.in/faq_commodities.aspx. Accessed November 7, 2017.

4. Commodity products Grain and Oilseed Hedger's Guide. Trades oftsnet. Available at: http://tradesofts.net/sitebuildercontent/sitebuilderfiles/hedgersguide.pdf. Accessed November 2, 2017.

5. DEY K. How producer firms can help growers by taking part in futures. Business Line. http://www.thehindubusinessline.com/markets/commodities/how-producer-firms-can-help-growers-by-taking-part-infutures/article7295195.ece. Published 2015. Accessed November 7, 2017.

6. Definition of 'Risk' - The Economic Times. The Economic Times. 2015. Available at: https://economictimes.indiatimes.com/definition/risk. Accessed November 7, 2017

7. Download Reports $\mid$ Ministry of Statistics and Program Implementation $\mid$ Government Of India. Mospinicin. 2017. Available at: http://mospi.nic.in/download-reports. Accessed November 7, 2017.

8. Delhi: Government of India Planning Commission; :1. Available at: http://www.planningcommission.nic.in/aboutus/committee/wrkgrp11/wg11_risk.pdf. Accessed November 7, 2017

9. Dey Kushankur (June 2015) 'How Producer Firms Can Help Growers By Taking Part In Futures'. Retrieved from Http://Economictimes.Indiatimes.Com/Definition/Risk.

10. Dr. Diwase Smita, Indian agriculture \&Agri business Management. New Delhi, Scientific publishers, 2014

11. Dr. Martin Ziegelbäck Follow. (2016, September 12). Price risk management_EN. Retrieved November 08, 2017, from https://www.slideshare.net/DrMartinZiegelbck/price-risk-managementen 
12. Dwivedi Y, Arun R. Joshi A. Producer Company-a new generation farmers institution. Scribd. 2007. Available at: https://www.scribd.com/document/85165514/Producer-Company. Accessed November 8, 2017.

13. Dwivedi, R. C. (1996) 'Role of co-operatives in rural economy', Indian Journal of Agricultural Economics, 51: 713-727.

14. Gill, S. S. (2004) 'Small farmers and Markets', Economic and Political Weekly: 2356-2358.

15. Hedging Guide. Slide share net. Available at: https://www.slideshare.net/VijayJoshi55/hedging-guide. Accessed November 8, 2017.

16. Hedging. Course hero com. 2017. Available at: https://www.coursehero.com/file/p48k7t2/Does-not-include-transaction-feesHedging-is-based-on-the-principle-that-cash/. Accessed November 8, 2017.

17. Hervé-Gruyer P, Hervé-Gruyer C, Coleman E, Howard M, Bodmar T. Producer Company | Cooperative | Chief Executive Officer. Scribd. Available at: https://www.scribd.com/document/85165514/Producer-Company. Accessed November 8, 2017.

18. Https://www.lme.com/what_contracts_futures.asp. Accessed November 8, 2017.

19. Https://www.Ime.com/what_contracts_futures.asp. Accessed November 8, 2017.

20. Icexindiacom. 2017. Available at: https://www.icexindia.com/Admin/pdfDownloadsfile/977_Research\%2 Oand\%20Education.pdf. Accessed November 8, 2017.

21. Kudumbashreeorg. Available at: http://kudumbashree.org/storagel/files/bsknk_faq\%20on\%20producer\%20companies.pdf. Accessed November 8, 2017.

22. Murray E. Producer Company Model-Current Status and Future Outlook: Opportunities for Bank Finance. wwwresearchgatenet. 2015.

Available

https://www.researchgate.net/profile/Emmanuel_Murray/publication/228888927_Producer_Company_Model-

Current_Status_and_Future_Outlook_Opportunities_for_Bank_Finance/links/58a6a3a0a6fdcc0e07865c78/Producer-

Company-Model-Current-Status-and-Future-Outlook-Opportunities-for-Bank-Finance.pdf. Accessed November 7, 2017.

23. NSEs Certification Financial Markets, Commodity market Module, Delhi, Retrieved from www.nseindia.com _NCFM _ Curriculum \& Study Material

24. Price. Pastradecom. 2017. Available at: https://www.pastrade.com/contracts/commodity-price.html\#close. Accessed November 8, 2017.

25. Risk Management and Commodity Markets. http://ussecorg. Available at: http://ussec.org/wpcontent/uploads/2012/08/Chap5.pdf. Accessed November 8, 2017.

26. Self-Study Guide to Hedging with Grain and Oilseed Futures and Options. Cmegroupcom. 2015. Available at: http://www.cmegroup.com/trading/agricultural/files/grain-oilseed-hedgers-guide.pdf. Accessed November 7, 2017.

27. Sharma, P. (2010) 'Promoting Farmer Producer Organizations to Mitigate Risk and Improve Market Access: Lessons and Challenges', Financing Agriculture, 42(7): 22-25.

28. Singh, K. and Pundir, R. (2000) Co-operatives and Rural Development in India: Institute of Rural Management.

29. Singh, S. (2009) Organic Produce Supply Chains in India: Organization and Governance: Allied Publishers.

30. Singh, S. (2012) 'New markets for smallholders in India-Exclusion, policy and mechanisms', Economic and Political Weekly, 47: 95-105. 
31. Swayambhu M. The Blue Revolution. wwwlinkedincom. 2015. Available at: https://www.linkedin.com/pulse/blue-revolutionmadhukar-swayambhu. Accessed November 7, 2017.

32. What is producer Inanswersyahoocom. Available at: https://in.answers.yahoo.com/question/index?qid=20091213020222AAnkhan. Accessed November 8, 2017. 
